\title{
Improving EFL argumentative writing: A dialogic critical thinking approach
}

Fahim, Mansoor

Allameh Tabataba'i University, Iran (drmfahim@yahoo.com)

Mirzaii, Mostafa $\$

Allameh Tabataba'i University, Iran (mustafa.mirzaei@yahoo.com)

Received: 14 January 2013 Available Online: 27 May 2013
Revised: 23 February 2013 DOI: $10.5861 / \mathrm{ijrs} 11.2013 .313$

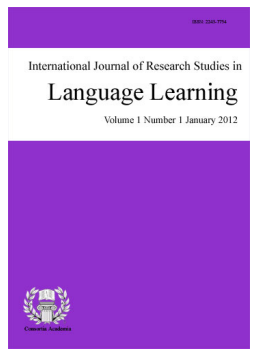

ISSN: 2243-7754 Online ISSN: 2243-7762

OPEN ACCESS

Accepted: 10 March 2013

\begin{abstract}
ELT has traditionally practiced the teaching of argumentative writing through conventional writing instruction and as such has disregarded critical thinking, a capability essential to argumentative writing. The present study, therefore, aimed at enhancing EFL argumentative writing through the coupling of writing instruction and dialogic critical thinking. To this aim, 48 Iranian EFL learners, selected through cluster sampling, were randomly assigned to either the experimental group-receiving writing instruction in conjunction with doing tasks involving dialogic critical thinking-or the control group, only receiving writing instruction. To compare the writing performances of the two groups, a pretest prior to the treatment and a posttest after the treatment were administered, both in the form of in-class 180-word four-paragraph argumentative essays within a time limit of 30 minutes. While both groups made statistically significant improvements in writing argumentatively, the results indicated that the coalescence of writing instruction and dialogic critical thinking led to superior performances.
\end{abstract}

Keywords: argumentative writing; writing instruction; critical thinking; dialogic critical thinking; Iranian EFL learners 


\section{Improving EFL argumentative writing: A dialogic critical thinking approach}

\section{Introduction}

Philosophers, psychologists, and educators have, throughout history, unanimously emphasized the art, science, and practice of thinking. Likewise, what the twentieth century witnessed, as cotton (1991) observes, was the emphasis placed upon the integral significance of the ability to engage in careful, reflective thinking. Cotton states that this type of thinking is currently "viewed in various ways: as a fundamental characteristic of an educated person, as a requirement for responsible citizenship in a democratic society, and, more recently, as an employability skill for an increasingly wide range of jobs" (p. 1). However, the central role thinking plays tends to be more manifest in the realm of education. This centrality of importance is reflected in Gelder's (2005) statement holding that "almost everyone agrees that one of the main goals of education, at whatever level, is to help develop general thinking skills ...." (p. 41).

It could be stated that all education involves the transmission of two knowledge types to learners-namely, knowledge of what to think and knowledge of how to think. Whereas the former knowledge type is concerned with the subject matter or discipline content, the latter features knowledge of the appropriate approach to understanding and evaluating this subject matter (Schafersman, 1991). Schafersman states that while we, as educators, generally "do an excellent job of transmitting the content of our respective academic disciplines, we often fail to teach students how to think effectively about this subject matter, that is, how to properly understand and evaluate it" (p. 1). According to Fisher (2001), "for many reasons, educators have been very interested in teaching 'thinking skills' of various kinds in contrast with teaching information and content" (p. 1). As such, Fisher states, the teaching of these thinking skills (referred to as critical thinking skills) should be done directly and explicitly so as to ensure transferability. Similarly, Scriven, and Paul (2004) argue that thinking is a natural process but which, if left to itself, tends to be distorted, not fully informed, and potentially prejudiced. Accordingly, excellence in thinking has to be cultivated.

Accentuating the desirability of teaching critical thinking skills, Arend (2009) aptly comments that "Instilling critical thinking abilities in students is a highly touted goal of ... education" (p. 2). Nevertheless, according to Scriven and Paul (2005), one should bear in mind the fact that critical thinking entails more than the mere acquisition of knowledge or a collection of processing skills, rather it is the progress, development, and continual use of analytical skills. Whereas both ELT researchers and practitioners deem critical thinking to be a capability with a great potential to improve EFL/ESL teaching and learning, it appears that the full potential of critical thinking has not, to date, been realized. Putting this in other words, Arend states that "Although critical thinking is a goal of ... education, instructors may not often be using the most effective methods to encourage students to use critical thinking strategies" (p. 2). Likewise, Willingham (2007) contends that "Virtually everyone would agree that a primary, yet insufficiently met, goal of schooling is to enable students to think critically" ( $p$. 8). Considering the importance of instilling critical thinking in learners and the significance of subsequent transfer of this to other contexts, the present study aimed at enhancing the teaching/learning of a complex mode of writing-argumentative writing-through making use of tasks engaging EFL learners in dialogic critical thinking.

\section{Theoretical background}

In regard to its immense significance, Hatcher and Spencer (2005) observe that critical thinking is an essential skill to be equipped with as it is required in the workplace, it could help to satisfactorily resolve mental and spiritual conflicts, and it can be resorted to in evaluating people, policies, and institutions, thereby avoiding social problems. Likewise, differentiating passive thinking form critical thinking, Duron, Limbach, and Waugh (2006) hold that "passive thinkers suffer a limited and ego-centric view of the world; they answer questions with 
Improving EFL argumentative writing: A dialogic critical thinking approach

yes or no and view their perspective as the only sensible one and their facts as the only ones relevant" (p. 160). In recent years, a considerable number of researchers, theoreticians, as well as sectors of society, including government and industry, have commenced to express mounting concerns about whether higher education is preparing students to meet the challenges they will face in the $21^{\text {st }}$ century (Beachboard \& Beachboard, 2010).

Despite the fact that this emergence of concerns over the place and status quo of critical thinking in today's education systems seems to be recent, critical thinking has been around for centuries in the guise of different labels and there is currently widespread recognition of its significance among researchers, theoreticians, and practitioners working in various disciplines. As Fisher (2001) states, "in recent years, 'critical thinking' has become something of a 'buzz word' in educational circles" (p. 1). Nonetheless, there is a striking lack of consensus as to how critical thinking can be defined. The American philosopher, psychologist, and educator John Dewey, in as early as 1909, defined critical thinking, under the then-label reflective thinking, as "active, persistent, and careful consideration of a belief or supposed form of knowledge in the light of the grounds which support it and the further conclusions to which it tends" (p. 9). With respect to the literature on critical thinking, three strands, each defining and conceptualizing critical thinking through a different approach, could be identified (Lewis \& Smith, 1993). These academic strands-philosophy, cognitive psychology, and the field of education-attempting to cater for their respective concerns, adopt different approaches to defining critical thinking.

\subsection{A philosophical approach to critical thinking}

The writings of Lipman (1988) and Paul (1992), as well as those of earlier philosophers, e.g., Socrates and Plato, epitomize the philosophical approach to defining and delineating critical thinking. This approach focuses on the hypothetical, idealized critical thinker, enumerating the qualities and characteristics of this person rather than the behaviors or actions the critical thinker can perform in real-life situations (Thayer-Bacon, 2000). Lipman (1988) defines critical thinking as "skillful, responsible thinking that facilitates good judgment because it relies upon criteria, is self-correcting, and is sensitive to context" (p. 39). Further, Paul (1992) maintains that critical thinking is "disciplined, self-directed thinking that exemplifies the perfections of thinking appropriate to a particular mode or domain of thought" (p. 9). In his subsequent writings, Paul (1995) suggests that mastery of critical thinking entails the application of a set of intellectual standards while thinking. As such, critical thinking is a purposeful type of thinking that is practiced on a systematic and purposeful basis. Moreover, as Paul puts it (1995), thinking about thinking in an attempt to enhance the thought process is integral to developing critical thinking.

Sternberg (1986) contends that the philosophical school of thought approaches the critical thinker as an ideal type, concentrating upon what people are capable of doing under the best of circumstances. Paul's (1992) reference to the phrase "perfections of thinking" (p. 9) attests to this contention. As such, a limitation this approach suffers from, when attempting to conceptualize critical thinking, is that it tends not to correspond to reality. Lai (2011), criticizing the practice of accentuating idealized critical thinkers and what capability they are endowed with, argues that "this approach may have less to contribute to discussions about how people actually think" (p. 5). Accordingly, it could be maintained that the philosophical approach, merely focusing on hypothesized competence viewed in a vacuum, loses sight of real-life performance.

\subsection{A cognitive psychological approach to critical thinking}

The second approach to defining critical thinking, advocated by the cognitive psychological school of thought, contrasts with the former approach in two ways (Lai, 2011). First, cognitive psychologists, and more specifically those adhering to the positivist, empiricist, experimental paradigm, generally focus their attention on how people actually think, rather than on how they could, or should, think under ideal conditions. Second, in preference to defining critical thinking by enumerating the attributes of the ideal critical thinker or listing the 
criteria of perfect thought, those working in cognitive psychology tend to define critical thinking by the types of behavior critical thinkers can exhibit. Typically, this approach to defining critical thinking, according to Lewis and Smith (1993), involves providing a list of the skills applied or procedures followed by critical thinkers, the process of which has been criticized by philosophers, recognizing it as reductionist.

Among the most renowned cognitive psychologists in this regard are Sternberg (1986), Burden and Byrd (1994), Halpern (1998), and Willingham (2007). Sternberg (1986) compartmentalizes critical thinking and observes that it is composed of "the mental processes, strategies, and representations people use to solve problems, make decisions, and learn new concepts" (p. 3). Further, Burden and Byrd (1994) conceptualize critical thinking as a higher-order thinking capacity that requires a set of cognitive skills. Similarly, Halpern (1998) holds that "the use of those cognitive skills or strategies that increase the probability of a desirable outcome" (p. 450) could be labeled critical thinking. Likewise, Willingham (2007) defines critical thinking as "seeing both sides of an issue, being open to new evidence that disconfirms your ideas, reasoning dispassionately, demanding that claims be backed by evidence, and deducing and inferring conclusions from available facts" (p. $8)$.

Moreover, according to Willingham, critical thinking has three key features-effectiveness, novelty, and self-direction. "Critical thinking is effective in that it avoids common pitfalls, such as seeing only one side of an issue, discounting new evidence that disconfirms your ideas...." (Willingham, ibid, p. 11). Critical thinking is novel, as Willingham maintains, in that one does not draw upon an already existing solution simply because of certain situational commonalities. To put it in different words, critical thinking entails finding novel ways of dealing with every unique situation. Last, Willingham observes that critical thinking is self-directed, i.e., autonomy and self-government on the part of the critical thinker should be observed throughout the whole process of thinking.

\subsection{An educational approach to critical thinking}

Educationists constitute the third group, attempting to contribute to the discussions about critical thinking. As regards language education, according to McPeck (1981), prior to the late 1980s, critical thinking was typically discussed in the domain of first language education. According to Fisher (2005), educationalists, generally, noticed some deficiency in the thinking of their students and devised some teaching interventions so as to directly address those thinking deficiencies. Nonetheless, as Ennis (1962) puts it, EFL/ESL theoreticians, as well as practitioners, have begun to take an interest in critical thinking. This, in turn, has led to heated debates about how it could be taught and used to enhance the current state of second language learning/teaching. To arrive at a workable answer, ELT educators need to first define the concept and enumerate its characteristic attributes.

Of the most prominent frameworks and/or taxonomies, delineating thinking skills, is that of Bloom (1956). Although Bloom's Taxonomy was first proposed in 1956 to be used for writing instructional objectives, it is still a highly worthwhile model for considering thinking skills and is a useful guide for checking whether students' thinking is being extended to a higher level. There are six levels of thinking in the model—namely, knowledge, comprehension, application, analysis, synthesis, and evaluation-the first three of which are generally thought of as lower-order thinking skills. Further, the three highest levels, i.e., analysis, synthesis, and evaluation, are frequently reported to reflect critical thinking (Kennedy, Fisher, \& Ennis, 1991). In conformity with Bloom's conception of thinking levels and the profound significance of higher-order thinking, Dressel and Mayhew (1954) contend that educational institutions are responsible for teaching students to go beyond the simple mental activities of recall and restatement of ideas and facts to the higher level skills and habits involved in critical thinking.

The educational approach to defining critical thinking, unlike the philosophical and cognitive psychological paradigms, benefits from considerable periods of experience and observation of student behavior and learning. 
This approach, nevertheless, lacks in clarity, the fact of which has rendered the educational approach not as amenable to instruction or assessment as are the philosophical and cognitive psychological traditions (Ennis, 1985). Despite the differences amongst the three schools of thought, there are a number of areas in which their arguments, contentions, and definitions overlap.

\subsection{Critical thinking and overlapping areas}

It is self-evident that different original concerns naturally result in utterly different proposals and outlooks. However, there are a number of areas in which one can trace signs of overlap. One overlapping area regards the particular abilities which critical thinking entails and with which a critical thinker is equipped. Put briefly, these abilities include 1) analyzing arguments, claims, or evidence (Facione, 1990; Halpern, 1998); 2) making inferences using inductive or deductive reasoning (Paul, 1992; Willingham, 2007); 3) judging or evaluating all aspects of arguments, cases, and situations (Case, 2005; Lipman, 1988); 4) making decisions or solving problems (Ennis,1985; Halpern, 1998; Willingham, 2007); 5) interpreting and explaining (Facione, 1990); and 6) asking and answering questions for clarification (Ennis, 1985).

A second area of overlap concerns a number of specific dispositions, as distinct and separate from critical thinking abilities (Facione, 1990, 2000), which critical thinkers possess. Facione defines critical thinking dispositions as "consistent internal motivations to act toward or respond to persons, events, or circumstances in habitual, yet potentially malleable ways" (p. 64). Open-mindedness, fair-mindedness, inquisitiveness, flexibility, the desire to be well-informed, the propensity to seek reason, and the willingness to entertain others' viewpoints constitute but some of these dispositions (Bailin, Case, Coombs, \& Daniels, 1999; Ennis, 1985; Facione, 1990; Halpern, 1998; Paul, 1992).

Another issue over which there seems to exist no disagreement concerns the significance of transferability. Reflecting upon this, Fisher (2005) states that how critical thinking is viewed and taught to learners is not a key concern, rather "a key concern of all such work is to ensure that students transfer the skills learned in one context to other contexts" (p. 3). It follows, as Fisher argues, "skills are transferable, i.e., if students learn general thinking skills in one context, they will be able to (and actually will) apply them to many other contexts, provided the teaching specifically aims at such transfer" (p. 5). Moreover, according to Fisher, despite the differences among different approaches to teaching critical thinking, what they all appear to encourage is the development of metacognition-thinking about one's thinking. As such, "They all require the participant to self-consciously adopt 'good' ways of thinking when faced with problems of whatever kind" (p. 3).

\subsection{Dialogic critical thinking}

Recognizing the specific abilities and dispositions critical thinking entails, specialists working in the field of education might raise a question as to how critical thinking could be taught. One presumably convincing answer to this question appears to be the engagement of learners in dialog, hence the term dialogic critical thinking. It follows that critical thinking and dialog are closely interconnected. Shor and Freire (1987) define dialog as "a moment where humans meet to reflect on their reality as they make and remake it" (p. 13). Elder and Paul (1994) consider holding dialogs to be part of the method of critical thinking, for dialog makes it possible to take the perspective of others into consideration, the act of which is a necessary prerequisite for the appraisal of truth claims. According to Shor and Freire, "dialog is a way to recreate knowledge as well as the way we learn" (p. 11), hence, the immense significance of dialogic education which is aimed at instructing for dialog as well as instructing through dialog. Resonating with this viewpoint, Lang (2000) argues that critical thinking is "a dialogical process that produces an increasingly sound, well-grounded, and valid understanding of a topic of issue, involves participants [in] developing and examining their ideas as fully as possible ... and examining and challenging the ideas of others" (p. 20).

The use of dialogic education, in general, and dialogic critical thinking, in particular, is prescribed by two 
perspectives. The first perspective, that is, the cognitive perspective, emphasizes the fact that social interaction affects cognitive elaboration processes (Dekker, Elshout-Mohr, \& Wood, 2004). Similarly, Frijters, Ten Dam, and Rijlaarsdam (2008) state that "language functions such as explaining, reasoning, and asking questions stimulate thinking and the development of knowledge" (p. 68). The second perspective, the social constructivist perspective, concentrates upon the process of becoming a member of a certain community (Wells, 2000, cited in Frijters, Ten Dam, \& Rijlaarsdam, 2008). Learning, in this context, is seen as dialog, a form of collaborative meaning co-construction (Ten Dam \& Volman, 2004). Lending credence to these two perspectives, Shor and Freire (1987) argue that "dialog is not a mere technique to achieve some cognitive results; dialog is a means to transform social relations in the classroom" (p. 11). But, could dialogic critical thinking enhance the teaching/learning of such a complex skill as writing?

\subsection{Argumentative writing}

Troia and Graham (2003) state that "Writing is one of the most complex literate activities in which children and adults engage" (p. 75). Recognizing this complexity, Mirzaii (2012b) states that "writing as a skill requires language learners to master a number of complex, rhetorical, linguistic, and mechanical conventions" (p. 140), the fact of which is complicated by the presence of various modes of writing. Accordingly, Richards and Schmidt (2010) introduce four types of non-creative writing modes-descriptive, narrative, expository, and argumentative writing, maintaining that a tacit consensus among EFL/ESL writing instructors is that novice writers should begin with the simplest mode-the descriptive essay—and gradually move towards learning the most complex one, the argumentative mode.

Richards and Schmidt further define argumentative writing as composition which "attempts to support a controversial point or defend a position on which there is a difference of opinion" (p. 337). As such, the ability to write argumentatively crucially depends on EFL/ESL learners' being equipped with an intellectual capacity for thinking in a critical manner. Therefore, the most significant prerequisite for the proper teaching of argumentative writing is that of fostering critical thinking by means of thought-provoking pedagogy. The vast majority of EFL writing instructors, nevertheless, approach the teaching of this mode in the same manner as when instructing other writing modes, i.e., narrative, descriptive, or expository.

\section{Significance and purpose of the study}

As stated above, dialogic education is a potentially adequate instructional technique for actuating critical thinking. It requires learners to process beyond the surface level of knowledge telling (Bereiter \& Scardamalia, 1987); the questions that the other participants ask stimulate further thinking and add other moral perspectives to the issue in question. Despite this perceived importance of dialogic critical thinking and the potential it has for enhancing various areas of ELT, the literature appears not to have fully addressed this potential. Further, despite its perceived potential to improve EFL/ESL writing, research, to date, seems to have principally attempted to investigate the impact of critical thinking on other areas of ELT (Fahim \& Nazari, 2012; Moafian \& Ghanizadeh, 2010; Vaseghi, Gholami, \& Barjesteh, 2012). More specifically, research attempting to enhance writing, in general, and argumentative writing, in particular, has investigated either the impact of writing instruction or written corrective feedback (Chandler, 2003; Ferris, 2004, 2006; Keh, 1990; Mirzaii, 2012a, 2012b, 2012c). To address these limitations, the present study adopted a dialogic critical approach to teaching and learning targeted at improving argumentative writing in an Iranian EFL context, and herein lies the significance of this study. To this end, the following null hypotheses were stated:

> $\mathrm{H}_{0}(1)$ : The pretest and posttest argumentative writing scores of the participants doing dialogic critical thinking tasks, along with receiving instruction on how to compose argumentative essays, are not significantly different.

$>\mathrm{H}_{0}$ (2): The pretest and posttest argumentative writing scores of the participants only receiving 
instruction on how to compose argumentative essays are not statistically significantly different.

$>\quad \mathrm{H}_{0}$ (3): The posttest argumentative writing scores of the participants doing dialogic critical thinking tasks, along with receiving instruction on how to compose argumentative essays, and those participants only receiving instruction on how to compose argumentative essays are not significantly different.

\section{Method}

\subsection{Design}

This quasi-experimental study followed a pretest-posttest design. Moreover, drawing upon Mackey and Gass (2005), the present study had a between-groups design. More specifically, since this study included an experimental group and a control group, the design took the form of control groups design, one of between groups design types. The design could more properly be schematically illustrated as in Figure 1.

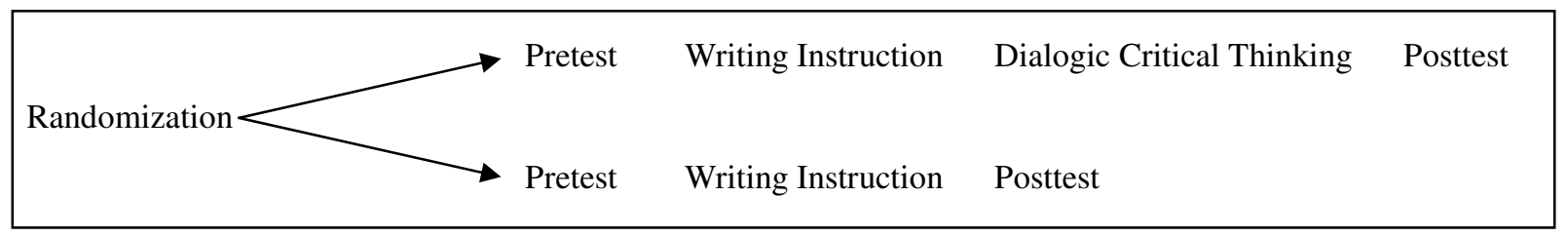

Figure 1. Study design and featured components

\subsection{Participants}

The participants of the study were selected from among EFL learners studying at the upper-intermediate level at Kish Institute of Science and Technology, Tehran, Iran. To arrive at a random sample, the researchers utilized cluster sampling in assigning the participants to the study. In other words, the unit of selection did not involve individuals, but classes of individuals being randomly selected from all existing classes at the institute. The whole selected sample was composed of 48 male EFL learners who varied in age from 17 to 41 years, with the average being 26 . These learners were subsequently required to compose a 180-word argumentative essay. Following this, those learners whose scores on the essay were within \pm 1 standard deviation of the mean score were recognized as the eligible participants of the study. Consequently, the resulting sample of participants constituted two separate groups, one taken as the experimental group (EG) consisting of 21 students and the other, the control group (CG), comprising 22 students.

\subsection{Study tools}

The tools utilized in the course of the present study included: 1) two written English tests (measurement tool), in the form of four-paragraph argumentative essays of about 180 words each, one serving pretest and the other one posttest purposes; 2) the Rubric for the Assessment of the Argumentative Essay, used as an analytic marking scheme; and 3) EG lesson material (instructional tool), utilized in order to instigate dialogic critical thinking.

\section{Written English Test}

The first tool used in this study was the written English test. This test, administered twice in the course of the study, served two purposes, i.e., ensuring homogeneity in terms of the ability to compose argumentative essays and fulfilling pretest and posttest requirements. To require the participants to write argumentative essays, the researchers selected the topics of the tests from the book titled "For and Against" authored by Alexander (1968). Further, to turn the topics into test rubrics, the researchers added the necessary corresponding instructions, time allocation, number of words, and additional explanations (see Appendix A). In order to analyze this tool in 
terms of validity of content and use, as a tool designed to measure EFL learners' argumentative writing ability, a panel of five experienced EFL instructors were required to impressionistically rate its usefulness and applicability on a scale of 0 to 100 . The average rating awarded was calculated to be 79 , the fact of which was reassuring enough to grant this tool as a valid measurement tool.

\section{Rubric for the Assessment of the Argumentative Essay}

The second tool was the Rubric for the Assessment of the Argumentative Essay which myteacherpages.com proposes as an analytic framework of writing criteria, comprising the components of an argumentative essay which should be taken into consideration when assigning a grade, hence, its applicability as an analytic marking scheme. Five broad categories-namely, introduction and conclusion, main points, organization, works cited, and mechanics-constitute this scheme. These categories are further explained and sub-classified into more detailed components which form the basis of assigning grades to compositions. Accordingly, the scores assigned can vary within a range of zero to fifteen (see Appendix B).

To validate this scoring scheme, the researchers asked a panel of five experienced EFL instructors to analyze the proposed components, as well as the sub-components. Upon conducting content analysis of this scoring tool, the panel unanimously agreed that both the components and the sub-components enjoy acceptable content and construct validity. Following this, a pilot study was conducted through which thirty EFL learners studying at the upper-intermediate level were required to write an argumentative essay. Three experienced EFL instructors were then required to score the essays using the Rubric for the Assessment of the Argumentative Essay. The inter-rater reliability coefficient was subsequently calculated to be 0.81 .

\section{EG Lesson Material}

To engage EG participants in dialogic critical thinking, the researchers designed a number of tasks to be done in pairs. In so doing, four topics, perceived to be more thought-provoking and controversial were selected from the book titled "For and Against" written by Alexander (1968). Subsequently, a simulated dialog between two students, discussing the topic in question, was written. Following the dialog, a number of questions were raised, requiring the participants to summarize, reflect upon, and analyze the opinions of the two students and to then express their own opinions about the topic (see Appendix C).

\subsection{Procedure}

The present study was conducted taking Iranian EFL learners, studying at the upper-intermediate level at Kish Institute of Science and Technology, as its participants. The four classes under investigation were held five times a week, with the whole term spanning five weeks and comprising 21 sessions. In total, 19 sessions were devoted to the treatment, excluding the first and final sessions since they were taken to administer the pretest and the posttest. In regard to the participants, an initial sample of 48 EFL upper-intermediate learners was selected. Following this, all these learners took the pretest in the first session, as a result of which five learners whose scores were not within \pm 1 standard deviation of the sample mean score were excluded from the study. Consequently, 43 eligible participants constituting four classes were randomly assigned to two groups, EG and CG, with the former comprising 21 and the latter including 22 participants.

What the course generally attempted to provide the learners with was a balanced mix of skills work as well as instruction on the language sub-skills, including grammar, pronunciation and vocabulary. Whereas CG participants only did the above and received instruction on how to compose argumentative essays, EG participants, in addition to doing the above and receiving writing instruction, were, once every four sessions, supplied with tasks aimed at engaging them in dialogic critical thinking. In so doing, the participants were put in pairs and were provided with dialogs between two imaginary students, previously designed by the researchers, talking about a particularly controversial topic. The EG participants were then required to read the dialogs together and do the follow-up activities. These follow-up activities mainly asked the participants to summarize, 
reflect on, and analyze the attitudes and opinions of the two imaginary students in the dialog, to assert with which they mostly agreed and why, and to finally express their very own attitudes towards and opinions about the topic in question.

As such, the only difference between EG and CG participants lied in the fact that the participants in the former group, in four sessions, were provided with tasks engaging dialogic critical thinking. Upon the provision of the treatment, both groups sat the posttest which was the same as the pretest in all respects aside from the topic assigned. The testing environment and condition were made uniform and were as similar as possible to those of the pretest. In order to avoid practice effect, nevertheless, the participants were required to compose 180-word argumentative writing essays within a time limit of 30 minutes on a topic which was different from that of the pretest. Similar to the pretest scoring procedure, these essays were subsequently scored with reference to the Rubric for the Assessment of the Argumentative Essay.

\section{Results and discussions}

As was previously stated, at the outset of the study, a sample of four classes comprising 48 EFL learners was selected. A pretest in the form of a 180-word argumentative essay was then administered. To determine the existence of any statistically significant difference between the ability levels in terms of argumentative writing, before the experiment began, an ANOVA F-test was run. Corresponding pretest descriptive statistics are presented in Table 1.

Table 1

Pretest Descriptive Statistics

\begin{tabular}{lccccc}
\hline \multicolumn{1}{c}{ Group } & Mean & Minimum & Maximum & Std. Deviation & $n$ \\
\hline Group 1 & 7.83 & 4.00 & 11.00 & 2.37 & 12 \\
Group 2 & 7.83 & 5.00 & 10.00 & 1.75 & 12 \\
Group 3 & 7.91 & 5.00 & 11.00 & 1.88 & 12 \\
Group 4 & 7.67 & 5.00 & 12.00 & 2.06 & 12 \\
\hline Note. Further, the ANOVA F-test results are indicated in Table 2 & & &
\end{tabular}

Note. Further, the ANOVA F-test results are indicated in Table 2.

Table 2

One-way ANOVA F-test Results

\begin{tabular}{lccccc}
\hline & Sums of square & $d f$ & Mean Square & $F$ & Sig. \\
\hline Between Groups & 0.39 & 3 & 0.13 & 0.032 & 0.99 \\
Within Groups & 180.92 & 44 & 4.11 & & \\
Total & 181.31 & 47 & & & \\
\hline
\end{tabular}

As Table 2 indicates, at the 0.05 level of significance and at 47 degrees of freedom, the p-value was significantly higher than the value of $\alpha$, i.e., $0.99>0.05$. Therefore, it was statistically proven that there was no significant difference between the mean scores of the four classes at the outset of the study.

\subsection{Investigation of null hypothesis 1}

In the first place, the pretest and posttest results of EG were taken into consideration in order to determine whether this group had made any improvements in composing argumentative essays (see Table 3 ). 
Fahim, M. \& Mirzaii, M.

Table 3

EG Pretest and Posttest Descriptive Statistics

\begin{tabular}{lcccc}
\hline \multicolumn{1}{c}{ Pair 1 } & Mean & Std. Deviation & Std. Error Mean & $\mathrm{n}$ \\
\hline EGPre & 8.00 & 1.76 & 0.38 & 21 \\
EGPost & 10.95 & 2.22 & 0.48 & 21 \\
\hline
\end{tabular}

As can be observed in Table 3, the participants in EG performed better on the posttest, the fact of which was indicative of the improvement they had made in the course of the experiment. However, to investigate if this improvement was statistically significant, a paired-samples t-test was run. The results are shown in Table 4.

Table 4

Paired-samples T-test on EG's Pretest and Posttest

\begin{tabular}{cccccc}
\hline & Mean & Std. Deviation & Std. Error Mean & $t$ & Sig. (2-tailed) \\
\hline Pair EGPre-EGPost & -2.95 & 1.47 & 0.32 & -9.23 & 0.000 \\
\hline
\end{tabular}

According to Table 4, the $\mathrm{T}_{\text {observed }}$ absolute value, at 20 degrees of freedom, was 9.23. As the Sig. (2-tailed) was less than 0.05 , this statistical test proved that the difference in mean scores of the pretest and posttest was statistically significant. This finding was not consonant with Null Hypothesis 1. This hypothesis was, therefore, statistically rejected.

\subsection{Investigation of null hypothesis 2}

As previously stated, CG participants were only given instruction on how to write argumentative essays. The second null hypothesis was formed to investigate whether CG made any improvement in argumentative writing. Table 5 presents descriptive statistics corresponding to the pretest and posttest results of this group.

Table 5

CG Pretest and Posttest Descriptive Statistics

\begin{tabular}{lllll}
\hline Pair 1 & Mean & Std. Deviation & Std. Error Mean & N \\
\hline CGPre & 7.45 & 1.63 & 0.35 & 22 \\
CGPost & 8.46 & 1.87 & 0.40 & 22 \\
\hline
\end{tabular}

As with EG participants, the participants in the control group made an improvement in writing argumentative essays. Nevertheless, it was necessary to run a paired-samples t-test so as to determine if this improvement was statistically significant (see Table 6).

Table 6

Paired-samples T-test on CG's Pretest and Posttest

\begin{tabular}{cccccc}
\hline & Mean & Std. Deviation & Std. Error Mean & $t$ & Sig. (2-tailed) \\
\hline Pair CGPre-CGPost & -1.18 & 1.71 & 0.36 & -3.25 & 0.004 \\
\hline
\end{tabular}

Regarding the $\mathrm{T}_{\text {observed }}$ absolute value which, at 21 degrees of freedom, was calculated to be 3.25, and taking the value of the Sig. (2-tailed) into consideration, 0.004, it was shown that the difference between the mean scores was statistically significant. In other words, the CG participants performed significantly better on the posttest, hence, the rejection of Null Hypothesis 2. 


\subsection{Investigation of null hypothesis 3}

Finally, it was intended to examine and compare the posttest mean scores of the two groups so as to determine if they differed statistically significantly. As with the analyses of the first two hypotheses, the corresponding descriptive statistics are first presented in Table 7.

Table 7

Descriptive Statistics for Paired sample T-test

\begin{tabular}{lcccc}
\hline Pair 1 & Mean & Std. Deviation & Std. Error Mean & $n$ \\
\hline EGPost & 10.94 & 2.22 & 0.48 & 21 \\
CGPost & 8.46 & 1.87 & 0.40 & 22 \\
\hline
\end{tabular}

In regard to the pretest and posttest mean scores, the CG participants gained a mean score of 7.45 which was lower than the pretest mean score of the EG participants (8.00), a difference which was previously shown not to be statistically significant. Nevertheless, the EG participants performed better on the posttest and obtained a mean score of 10.95, as compared to that of the CG participants (8.64). Put in other words, the mean gain of EG was computed to be 2.95 , while that of CG was calculated to be 1.19 . In order to determine the existence of any statistically significant difference between the two groups' mean scores on the posttest, an independent-samples t-test was run, the results of which can be viewed in Table 8.

\section{Table 8}

Independent-samples T-test on Posttest Mean Scores

\begin{tabular}{lclllll}
\hline & $F$ & Sig. (Levene's Test) & $T$ & $d f$ & Sig. (2-tailed) & Mean Difference \\
\hline Equal Variances Assumed & 3.30 & 0.77 & 5.71 & 41 & 0.000 & 2.32 \\
\hline
\end{tabular}

As Table 8 indicates, the Sig. value of the Levene's Test for Equality of Variances exceeded 0.05. It was, therefore, concluded that the variability in the two conditions was the same. Further, the $\mathrm{T}_{\text {observed }}$ value was 5.71 at 41 degrees of freedom. Moreover, since the Sig. (2-tailed) was lower than the alpha level, i.e., 0.05, this statistical test confirmed that there was a statistically significant difference between the writing performance of the two groups on the posttest. Consequently, this hypothesis was statistically rejected.

Due to the fact that the means of the participants in both groups showed an increase from the pre-test to the post-test, it can be claimed that the practice of instructing EFL learners on how to write argumentatively had a positive effect on the learning of this mode of writing. The accompanying of this instruction with dialogic critical thinking, nevertheless, proved to have a great potential for improving thinking critically, in general, and composing argumentative essays, in particular. Therefore, it can be contended that while language learners tend to benefit from explicit writing instruction, requiring them to think critically, specifically through dialog, can both expedite and boost their learning as regards argumentative writing.

\section{Conclusions}

The purpose of the present study was three-fold. First, it examined the impact of writing instruction in how to compose argumentatively on the quality of argumentative essays. Second, it investigated the combined effects of writing instruction and dialogic critical thinking on the quality of argumentative writing. Last, it was attempted to determine which approach-mere writing instruction or writing instruction in conjunction with dialogic critical thinking - could better guarantee to enhance EFL learners' ability to compose argumentative essays. In the course of the study, CG participants received instruction in argumentative writing whereas EG participants, having initially been given instruction in argumentative writing, did tasks engaging them in dialogic critical thinking. 
The findings of this study were in line with the contention that the provision of writing instruction can enhance EFL/ESL learners' ability to compose texts (Arend, 2009; Bai, 2009; Mirzaii, 2012b, 2012c; Singer \& Scollay, 2006; Troia \& Graham, 2003). With respect to dialogic critical thinking, this study arrived at results which were in keeping with Frijters, Ten Dam, and Rijlaarsdam (2008) who contend that "dialogic learning results in a more positive effect on the critical thinking competences of learners, both in terms of generative fluency of reasoning and quality of value orientation" (p. 66). The results of this study, more specifically, dovetail with Stapleton (2002) who studied Japanese EFL learners' attitudes towards thinking critically and writing in a critical manner. Stapleton argues that while Asian EFL learners tend to possess "a firm grasp of elements of critical thinking" (p. 250), writing instructors should no longer "hesitate to introduce critical thinking and deductive rhetorical writing styles" (p. 256), for this very introduction to critical thinking enables these learners to grow more competent in terms of both thinking skills and argumentative writing.

In light of the findings of the present study, a number of pedagogical implications were arrived at and are briefly discussed below. First and foremost, the findings of this study are indicative of the plausibility of the application of dialogic critical thinking tasks and their profound impact on writing pedagogy. EFL/ESL practitioners could, thus, incorporate these tasks in their instruction so as to enhance the writing ability of learners. Moreover, as dialogic critical thinking tasks, by their very nature, engage learners in dialog, they enjoy a great potential for bettering speaking ability, the fact of which was voiced by the participants of this study. Accordingly, textbook writers and curriculum developers are highly recommended to include these types of tasks as a core component of instruction, for engaging learners, in general, and EFL/ESL learners, in specific, in critical thinking tasks is a desirable goal of instruction. Last, but by no means the least, educators are recommended to recall the fact that critical thinking skills bring about "self-directed, self-disciplined, self-monitored, and self-corrective thinking" (Paul \& Elder, 2006). In turn, these thinking types "could aid learners in becoming more independent, hence, the occurrence of more autonomous, and consequently, more meaningful learning" (Mirzaii, 2012c, p. 144).

Finally, several limitations, as well as delimitations, to this study must be noted. First, the participants included were all male EFL learners, ranging in age from 17 to 41 . As such, neither female EFL learners nor young EFL learners were studied. Further, the study was limited to written production, and hence did not take account of oral production. Moreover, due to logistical considerations-time and cost-and in order to investigate the effectiveness of dialogic critical thinking tasks on the participants' writing performances, the teacher-researcher decided to only study upper-intermediate-level EFL learners and, therefore, did not include learners studying at other levels of English proficiency. All the aforementioned limitations and delimitations, of which the reader should be cautious, imply the fact that the results cannot be generalized to other dissimilar contexts.

\section{References:}

Alexander, L. G. (1968). For and against. Harlow: Longman Group Ltd.

Arend, B. (2009). Encouraging critical thinking in online threaded discussions. Journal of Educators Online, $6(1), 1-23$.

Bai, H. (2009). Facilitating students' critical thinking in online discussion: An instructor's experience. Journal of Interactive Online Learning, 8(2), 156-164.

Bailin, S., Case, R., Coombs, J. R., \& Daniels, L. B. (1999). Conceptualizing critical thinking. Journal of Curriculum Studies, 31(3), 285-302. http://dx.doi.org/10.1080/002202799183133

Beachboard, M. R., \& Beachboard, J. C. (2010). Critical-thinking pedagogy and student perceptions of university contributions to their academic development. International Journal of an Emerging Transdiscipline, 13, 53-71.

Bereiter, C., \& Scardamalia, M. (1987). The psychology of written composition. Hillsdale, NJ: Erlbaum.

Bloom, B. S. (1956). Taxonomy of educational objectives: The classification of educational goals. New York: David McKay. 
Improving EFL argumentative writing: A dialogic critical thinking approach

Burden, P. R., \& Byrd, D. M. (1994). Methods for effective teaching. Boston: Allyn and Bacon.

Case, R. (2005). Moving critical thinking to the main stage. Education Canada, 45(2), 45-49.

Chandler, J. (2003). The efficacy of various kinds of error correction for improvement of the accuracy and fluency of L2 student writing. Journal of Second Language Writing, 12(3), 267-296. http://dx.doi.org/10.1016/S1060-3743(03)00038-9

Cotton, K. (1991). Teaching thinking skills. Retrieved February 11, 2012, from http://hppa.spps.org/uploads/teaching_thinking_skills.pdf

Dekker, R., Elshout-Mohr, M., \& Wood, T. (2004). Working together on assignments: multiple analysis of learning events. In J. van der Linden \& P. Renshaw (Eds.), Dialogic learning (pp. 145-170). Dordrecht, the Netherlands: Kluwer. http://dx.doi.org/10.1007/1-4020-1931-9_8

Dewey, J. (1909). How we think. Boston, MA: D.C. Heath and Co.

Dressel, P. L, \& Mayhew, L. B. (1954). General education: Exploration in education. Washington, DC: American Council on Education.

Duron, R., Limbach, B., \& Waugh, W. (2006). Critical thinking for any discipline. International Journal of Teaching and Learning in Higher Education, 17(2), 160-166.

Elder, L., \& Paul, R. W. (1994). Critical thinking: Why we must transform our teaching. Journal of Developmental Education, 18(1), 34-35.

Ennis, R. H. (1962). A concept of critical thinking. Harvard Educational Review, 32, 82-111.

Ennis, R. H. (1985). A logical basis for measuring critical thinking skills. Educational Leadership, 43(2), 44-48.

Facione, P. A. (1990). Critical thinking: A statement of expert consensus for purposes of educational assessment and instruction. Millbrae, CA: The California Academic Press.

Facione, P. A. (2000). The disposition toward critical thinking: Its character, measurement, and relationship to critical thinking skill. Informal Logic, 20(1), 61-84.

Fahim, M., \& Nazari, O. (2012). Practicing action research for enhancing critical thinking. Journal of Science, 2(1), 84-89.

Ferris, D. R. (2004). The 'grammar correction' debate in L2 writing: Where are we, and where do we go from here? (and what do we do in the meantime...?) Journal of Second Language Writing, 13(1), 49-62. http://dx.doi.org/10.1016/j.jslw.2004.04.005

Ferris, D.R. (2006). Does error feedback help student writers? New evidence on the short- and long-term effects of written error correction. In K. Hyland \& F. Hyland (Eds.), Feedback in second language writing: Contexts and issues (pp. 81-104). Cambridge: Cambridge University Press. http://dx.doi.org/10.1017/CBO9781139524742.007

Fisher, A. (2001). Critical thinking: An introduction. Cambridge: Cambridge University Press.

Fisher, A. (2005). Thinking skills and admission to higher education. Retrieved February 17, 2013, from http://www.cambridgeassessment.org.uk/ca/digitalAssets/113982/ThinkingSkills.pdf.

Frijters, S., Ten Dam, G., \& Rijlaarsdam, G. (2008). Effects of dialogic learning on value-loaded critical thinking. Learning and Instruction, 18(2008), 66-82. http://dx.doi.org/10.1016/j.learninstruc.2006.11.001

Gelder, T. V. (2005). Teaching critical thinking: Some lessons from cognitive science. College Teaching, 53(1), 41-46. http://dx.doi.org/10.3200/CTCH.53.1.41-48

Halpern, D., F. (1998). Teaching critical thinking for transfer across domains: Dispositions, skills, structure training, and metacognitive monitoring. American Psychologist, 53(4), 449-455. http://dx.doi.org/10.1037/0003-066X.53.4.449

Hatcher, D. L., \& Spencer, L. A. (2005). Reasoning and writing: From critical thinking to composition. Boston: American Press.

Keh, L. C. (1990). Feedback in the writing process: a model and methods for implementation. ELT Journal, 44(4), 294-304. http://dx.doi.org/10.1093/elt/44.4.294

Kennedy, M., Fisher, M. B., \& Ennis, R. H. (1991). Critical thinking: Literature review and needed research. In L. Idol \& B.F. Jones (Eds.), Educational values and cognitive instruction: Implications for reform (pp. 11-40). Hillsdale, New Jersey: Lawrence Erlbaum \& Associates.

Lai, E., R. (2011). Critical thinking: A literature review. Retrieved February 21, 2011, from 
http://www.pearsonassessments.com/research

Lang, D. (2000). Critical thinking in web courses: An oxymoron? Syllabus, 14(2), 20-24.

Lewis, A., \& Smith, D. (1993). Defining higher order thinking. Theory into Practice, 32(3), 131-137. http://dx.doi.org/10.1080/00405849309543588

Lipman, M. (1988). Critical thinking: What can it be? Educational Leadership, 46(1), 38-43.

Mackey, A., \& Gass. S. M. (2005). Second language research. New Jersey: Lawrence Erlbaum Associates.

McPeck, F. (1981). Critical thinking and education. New York: St Martin's Press.

Mirzaii, M. (2012a). The effect of oral conferencing and peer response on Iranian EFL learners' writing achievements. Iranian EFL Journal, 8(3), 285-300.

Mirzaii, M. (2012b). Consciousness-raising instruction and its effect on Iranian EFL learners' use of the mechanics of writing. Iranian EFL Journal, 8(5), 139-156.

Mirzaii, M. (2012c). A comparative study of the impact of oral conferencing and consciousness-raising instruction on Iranian EFL learners' writing performance. Unpublished master's thesis, Iran University of Science and Technology, Tehran, Iran.

Moafian, F., \& Ghanizadeh, A. (2010). On the relationship between critical thinking and self-efficacy: A case of EFL teachers in language institutes. Journal of Faculty of Letters and Humanities, 5(16/17), 77-96.

Paul, R. W. (1992). Critical thinking: What, why, and how? New Directions for Community Colleges, 77, 3-24. http://dx.doi.org/10.1002/cc.36819927703

Paul, R. W. (1995). Critical thinking: How to prepare students for a rapidly changing world. Dillon Beach, CA: Foundation for Critical Thinking.

Paul, R. W., \& Elder, L. (2006). The miniature guide to critical thinking: Concepts and tools. Retrieved February 16, 2013, from http://www.criticalthinking.org/files/Concepts_Tools.pdf

Richards, J. C., \& Schmidt, R. (2010). Longman dictionary of language teaching and applied linguistics (4 ${ }^{\text {th }}$ ed.). London: Longman (Pearson Education).

Schafersman, D. (1991). An introduction to critical thinking. Retrieved December 24, 2011, from http://www.freeinquiry.com/critical-thinking.html

Scriven, M., \& Paul, R. (2004). The critical thinking community. Retrieved February 19, 2013, from http://www.criticalthinking.org/aboutCT/definingCT.shtml

Scriven, M., \& Paul, R. (2005). Defining critical thinking. Retrieved February 17, 2013, from http://www.criticalthinking.org/aboutCT/definingCT.cfm

Shor, I., \& Freire, P. (1987). What is the "dialogic method" of teaching? Journal of Education, 169(3), 11-31.

Singer, N. R., \& Scollay, D. (2006). Increasing student achievement in writing through teacher inquiry: An evaluation of professional development impact. Berkeley, CA: National Writing Project.

Stapleton, P. (2002). Critical thinking in Japanese L2 writing: Rethinking tired constructs. ELT Journal, 56(3), 250-257. http://dx.doi.org/10.1093/elt/56.3.250

Sternberg, R. J. (1986). Critical thinking: Its nature, measurement, and improvement. Retrieved June 12, 2012, from http://eric.ed.gov/PDFS/ED272882.pdf

Ten Dam, G., \& Volman, M. (2004). Critical thinking as a citizenship competence: Teaching strategies. Learning \& Instruction, 14(4), 359-379. http://dx.doi.org/10.1016/j.learninstruc.2004.01.005

Thayer-Bacon, B. J. (2000). Transforming critical thinking: Thinking constructively. New York: Teachers College Press.

Troia, G. A., \& Graham, S. (2003). Effective writing instruction across the grades: What every educational consultant should know. Journal of Educational and psychological Consultation, 14(1), 75-89. http://dx.doi.org/10.1207/S1532768XJEPC1401_04

Vaseghi, R., Gholami, R., \& Barjesteh, H. (2012). Critical thinking: An influential factor in developing English reading comprehension performance. Advances in Asian Social Science, 2(1), 401-410.

Willingham, D., T. (2007). Critical thinking: Why is it so hard to teach? American Educator, 27, 8-19. 
Appendix A

\section{Written English Test}

\section{Topic 1}

You should spend about 30 minutes writing about the following topic.

Any form of education other than co-education is simply unthinkable.

To what extent do you agree with the above statement?

Write at least 180 words.

Topic 2

You should spend about 30 minutes writing about the following topic.

Only stricter traffic laws can prevent accidents.

To what extent do you agree with the above statement?

Write at least 180 words. 


\section{Rubric for the Assessment of the Argumentative Essay}

\begin{tabular}{|c|c|c|c|c|}
\hline & 3 & 2 & 1 & 0 \\
\hline $\begin{array}{l}\text { INTRODUCTION } \\
\text { Background/History } \\
\text { Define the Problem } \\
\text { Thesis Statement }\end{array}$ & $\begin{array}{l}\text { Well-developed } \\
\text { introduction engages the } \\
\text { reader and creates interest. } \\
\text { Contains detailed } \\
\text { background information } \\
\text { and a clear explanation of } \\
\text { the problem. } \\
\text { Thesis clearly states a } \\
\text { significant and compelling } \\
\text { position. }\end{array}$ & $\begin{array}{l}\text { Introduction creates } \\
\text { interest and contains } \\
\text { background information. } \\
\text { Thesis clearly states the } \\
\text { problem. }\end{array}$ & $\begin{array}{l}\text { Introduction adequately } \\
\text { explains the background of } \\
\text { the problem, but may lack } \\
\text { detail. Thesis states the } \\
\text { problem. }\end{array}$ & $\begin{array}{l}\text { Background details are a } \\
\text { random collection of } \\
\text { information, unclear, or } \\
\text { not related to the topic. } \\
\text { Thesis or problem is vague } \\
\text { or unclear. }\end{array}$ \\
\hline $\begin{array}{l}\text { MAIN POINTS } \\
\text { Body Paragraphs } \\
\text { Refutation } \\
\text { Conclusion }\end{array}$ & $\begin{array}{l}\text { Well-developed main } \\
\text { points directly related to } \\
\text { the thesis. Supporting } \\
\text { examples are concrete and } \\
\text { detailed. } \\
\text { Refutation acknowledges } \\
\text { opposing view logically } \\
\text { and clearly. Conclusion } \\
\text { effectively wraps up and } \\
\text { goes beyond restating the } \\
\text { thesis. } \\
\text { Commentary is logical and } \\
\text { well thought out. }\end{array}$ & $\begin{array}{l}\text { Three or more main points } \\
\text { are related to the thesis, } \\
\text { but one may lack details. } \\
\text { Refutation paragraph } \\
\text { acknowledges the } \\
\text { opposing view and } \\
\text { summarizes points. } \\
\text { Conclusion effectively } \\
\text { summarizes } \\
\text { topics. Commentary is } \\
\text { present. }\end{array}$ & $\begin{array}{l}\text { Three or more main points } \\
\text { are present, }\end{array}$ & $\begin{array}{l}\text { Less than three main } \\
\text { points, and/or poor } \\
\text { development of ideas. } \\
\text { Refutation missing or } \\
\text { vague. Conclusion does } \\
\text { not summarize main } \\
\text { points. } \\
\text { Commentary is not } \\
\text { present. }\end{array}$ \\
\hline $\begin{array}{l}\text { ORGANIZATION } \\
\text { Structure } \\
\text { Transitions }\end{array}$ & $\begin{array}{l}\text { Logical progression of } \\
\text { ideas with a clear structure } \\
\text { that enhances the } \\
\text { thesis. Transitions are } \\
\text { mature and graceful. }\end{array}$ & $\begin{array}{l}\text { Logical progression of } \\
\text { ideas. Transitions are } \\
\text { present equally throughout } \\
\text { essay. }\end{array}$ & $\begin{array}{l}\text { Organization is clear. } \\
\text { Transitions are present. }\end{array}$ & $\begin{array}{l}\text { No discernable } \\
\text { organization. Transitions } \\
\text { are not present. }\end{array}$ \\
\hline $\begin{array}{l}\text { MECHANICS AND } \\
\text { STYLE } \\
\text { Sentence flow, variety } \\
\text { Diction } \\
\text { Spelling, punctuation, } \\
\text { capitalization }\end{array}$ & $\begin{array}{l}\text { Writing is smooth, skillful } \\
\text { and coherent. Sentences } \\
\text { are strong and expressive } \\
\text { with varied structure. } \\
\text { Diction is consistent and } \\
\text { words well chosen. } \\
\text { Punctuation, spelling, } \\
\text { capitalization are correct } \\
\text { with no errors. }\end{array}$ & $\begin{array}{l}\text { Writing is clear and } \\
\text { sentences have varied } \\
\text { structure. Diction is } \\
\text { consistent. Punctuation, } \\
\text { spelling, capitalization are } \\
\text { generally correct, with few } \\
\text { errors. (1-2) }\end{array}$ & $\begin{array}{l}\text { Writing is clear, but } \\
\text { sentences may lack } \\
\text { variety. } \\
\text { Diction is appropriate. } \\
\text { A few errors in } \\
\text { punctuation, spelling, } \\
\text { capitalization. (3-4) }\end{array}$ & $\begin{array}{l}\text { Writing is confusing, hard } \\
\text { to follow. } \\
\text { Contains fragments and/or } \\
\text { run-on sentences. } \\
\text { Inappropriate diction. } \\
\text { Distracting errors in } \\
\text { punctuation, spelling, } \\
\text { capitalization. }\end{array}$ \\
\hline $\begin{array}{l}\text { SOURCES } \\
\text { Use of sources } \\
\text { Format } \\
\text { Relevant/reliable }\end{array}$ & $\begin{array}{l}\text { Sources are smoothly and } \\
\text { logically integrated into } \\
\text { the text, and clearly } \\
\text { explain the } \\
\text { ideas. Accurate format. } \\
\text { Sources are relevant and } \\
\text { reliable. }\end{array}$ & $\begin{array}{l}\text { Sources are integrated into } \\
\text { the text, and accurately } \\
\text { documented using correct } \\
\text { format. Sources are } \\
\text { relevant and reliable. }\end{array}$ & $\begin{array}{l}\text { Source material is used. } \\
\text { Sources are accurately } \\
\text { documented, may contain } \\
\text { a few minor errors in } \\
\text { format. }\end{array}$ & $\begin{array}{l}\text { Lacks sources and/or } \\
\text { sources are not accurately } \\
\text { documented. Format is } \\
\text { incorrect for all sources. }\end{array}$ \\
\hline
\end{tabular}

Introduction

Main Points

Organization

Mechanics/Style

Sources

Total Points $=$ grade of

Grade Equivalent (maximum of 15 points):

$$
\begin{aligned}
& A=13-15 \text { points } \\
& B=10-12 \text { points } \\
& C=7-9 \text { points } \\
& D=4-6 \text { points } \\
& F=0-3
\end{aligned}
$$


Appendix C

\section{Dialogic Critical Thinking Lesson Material}

Task 1

Read the following dialog in pairs.

Dennis and David, two old school friends, are watching a documentary on the issue of "Television and the harm it does."

Dennis: Wow, look at the diagram. It says over forty per cent of children below the age of four spend an average of four hours a day watching TV.

David: Yeah, that's really surprising.

Dennis: And look, it also says scientists believe this early exposure to TV programs does irreparable harm to these children....

David: For example, exposure to trashy material and wrong messages like bad language, violence, and sex.

Dennis: What is more?

David: Well, it also says that all this time can more profitably be spent talking to parents, playing with them, and the like.

Dennis: You can say that again. And what else?

David: Erm..., it is mentioned too that watching too much TV results inactivity and this leads to ensuing physical, as well as mental, problems.

Dennis: Right, TV is just a time waster, isn't it?

David: It seems so. But, don't you think this is a black picture drawn of TV?

Dennis: What do you mean?

David: I mean, look, TV is not all that bad....

Dennis: Really? Can you tell me some of the good things TV offers to these poor children?

David: Yeah. These poor children can, for instance, watch the very many educational programs made specifically for them and learn a lot. Don't you remember the cartoon our teachers played for us when we were at primary school? We learnt so many different things, such as mathematical operations, the English and French alphabet, and so on.

Dennis: Ok, you might be right. But that all happened at school. It was very well programmed, I agree. When it comes to home and parents, children seem to be unstoppable and uncontrollable....

David: I don't think so. Children can be taught how and when to use TV. Plus, access can be controlled by parents.

Dennis: But, still I think TV is a bad thing.

David: Dennis, suppose you had children and that you didn't have any time to take them to the movies. What would you do? Dennis: I think I'd call a baby-sitter to ....

David: No, there's no need for that. You could simply turn on TV and choose a suitable edutainment and ask you children to watch it. See, TV is not all that bad.

Dennis: Well, I think you are right.

TV, as the documentary showed, does irreparable harm to children. Dennis and David expressed their opinions regarding this idea. Who do you agree with and why? 
Fahim, M. \& Mirzaii, M.

Task 2

Compulsory military service should be abolished in all countries

Read the following dialog in pairs.

Peter is about to commence soldiering and has to say goodbye to one of his best friends, Michael. Michael feels he will miss Peter and is sad about it. They are sitting together in Peter's garden and talking about old school memories. Suddenly, Michael, feeling very upset, raises the issue "Compulsory military service should be abolished in all countries."

Michael: You know, Peter, I think doing military service is a laborious job, isn't it?

Peter: It certainly is.

Michael: It also takes almost eighteen months to do, with a three-month training period.

Peter: It seems so.

Michael: But, don't you think it's just a time waster?

Peter: Sorry?

Michael: I mean the time spent doing national service can more profitably be spent doing something constructive.

Peter: Well, I'm not really sure about that. What I believe is every free country should possess a prepared army so that it can defend itself at times of war.

Michael: There's some truth in that, but do you think it's right to draft the youth and force them to serve in the army?

Peter: Erm...Not everyone is drafted, you know. There are a number of criteria you should meet to be drafted. Not all people are naturally suited to be in the military. But I think it is worth doing because doing military service teaches the youth some discipline.

Michael: You might be right.

Peter: Besides, if there were no draftees in the army, our country would have to pay huge sums of money to call for mercenaries.

Michael: Yeah, I agree. But, I think drafting, I mean forcing people to join the army, is not a good idea. That you force someone to do something makes them do it not enthusiastically enough.

Peter: Well, maybe it's better to inform the general public of the pros of doing national service. In that case, they will join voluntarily and will be more united. All that said, I believe doing military service instills in youngsters a sense of pride in their country.

Michael: You can say that again. But, that pride will result provided that they doing national service is not compulsory.

Peter: I agree. But, what if not enough people volunteer to join? Then, it should be mandatory, shouldn't it?

Michael: I don't think so, really...

As is evident above, while Michael is of the idea that compulsory military service should not be practiced, Peter believes it is vital for every free country, whether compulsory or voluntary. Who do you agree with and why? 